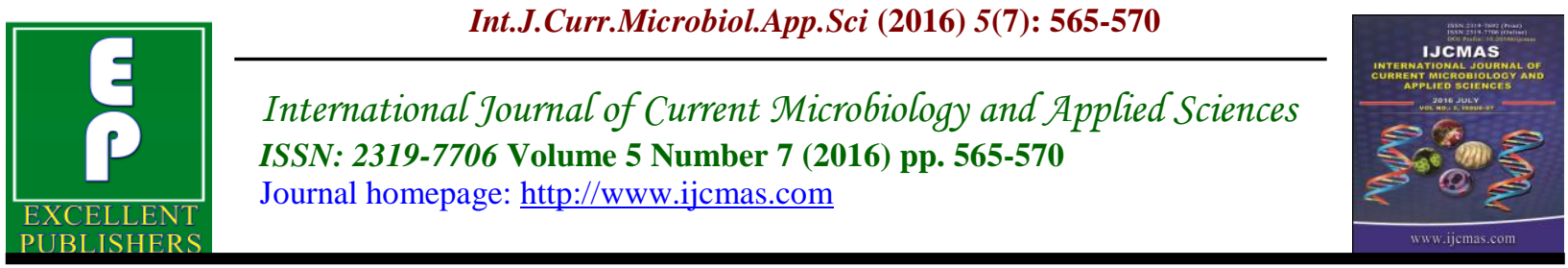

Original Research Article

http://dx.doi.org/10.20546/ijcmas.2016.507.062

\title{
Phyto-Diversity on Campus of K.M. Government College Narwana, India
}

\author{
Surender Kumar ${ }^{1}$, Sunita Duggal ${ }^{2}$, J.S. Laura ${ }^{3}$, Narender Singh ${ }^{4}$ and Rajdeep Kudesia ${ }^{5}$ \\ ${ }^{1}$ Department of Botany, K.M. Govt. P.G. College Narwana, Jind, India \\ ${ }^{2}$ Department of Botany, Govt. P.G. College Jind (Haryana), India \\ ${ }^{3}$ Department of Environmental Science, M.D. University, Rohtak, India \\ ${ }^{4}$ Department of Botany, Kurukshetra University Kurukshetra, India \\ ${ }^{5}$ Department of Botany, Bundelkhand University Jhansi, Utter Pradesh, India \\ *Corresponding author
}

\begin{tabular}{|c|c|}
\hline & A B S T R A C T \\
\hline & \multirow{7}{*}{$\begin{array}{l}\text { A field appraisal on plant diversity of K.M. Government College campus Narwana } \\
\text { was conducted during } 15 \text { January, } 2016 \text { to } 31 \text { January, } 2016 \text {. Study was performed } \\
\text { in all parts of the study area and plants were collected to prepare herbarium. } \\
\text { Herbaceous flora was excavated as a whole whereas in case of shrubs and trees, } \\
\text { only the tender twigs bearing flowers and fruits were taken. The dried specimens } \\
\text { were pasted on the herbarium sheets. The herbarium sheets were protected against } \\
\text { damage from insect and fungal pathogens by poisoning the sheets with } 1 \% \\
\text { mercuric chloride and naphthalene balls. After field survey and herbarium } \\
\text { preparation, all plants were identified by botanical name and family with the help } \\
\text { of available literature. The total plants species recorded, indicated the heterogenous } \\
\text { floristic composition in the college campus. Maximum species diversity was } \\
\text { recorded of angiosperms among spermatophytes. Herbaceous genera were recorded } \\
\text { more in number than the genera of shrubs and trees. The researchers can exploit } \\
\text { this information in planning of sustainable utilization of these resources in and } \\
\text { around Narwana town. }\end{array}$} \\
\hline & \\
\hline $\begin{array}{l}\text { Narwana, } \\
\text { Herbarium, } \\
\text { Field survey, } \\
\text { Phyto-diversity. }\end{array}$ & \\
\hline Article Info & \\
\hline & \\
\hline le Online: & \\
\hline 10 & \\
\hline
\end{tabular}

\section{Introduction}

India is one of the 12 "mega-diversity" countries in the world and this country has a forest area of $23.81 \%$ of the country's geographical area. Mankind has been utilizing plants for food and medicinal purpose since the time immemorial. Therefore various aspects of plants towards health, economic value, sustainable utility, their conservation, floral assessment and documentation are necessary. India is a rich center of plants diversity.
Distribution of plants depends on their genetic makeup, various environmental factors like temperature, water and other edaphic factors (Curtis and Cottom, 1956; Phillips, 1959; Misra, 1968). Plant diversity is the most important feature, which plays a vital role in complexity of natural ecosystems. The present paper is an attempt to know the distribution of plant diversity on campus of K.M. Government College Narwana, covering more than eight acres of 
open area in addition to lawns, garden, teaching and administrative blocks. The present research has been carried out in K.M. Government College Campus Narwana (India) to explore the diversity of plants and for sustainable utilization of available plant resources. These findings will pave the way towards sustainable development in this era of indiscriminate collection of plants and their products. Besides this, results will give a bird's eye view on existing plant diversity in and around Narwana municipal area especially on spermatophytes.

\section{Materials and Methods}

The field study was carried out during 15 January, 2016 to 31 January,2016 in the campus of K.M. Government College Narwana (India). Study was performed in all parts of the study area and plants were collected to prepare herbarium. Herbaceous flora was excavated as a whole whereas in case of shrubs and trees, only the tender twigs bearing flowers and fruits were taken. The dried specimens were pasted on the herbarium sheets (Jain and Rao, 1977). The herbarium sheets were protected against damage from insect and fungal pathogens by poisoning the sheets with $1 \%$ mercuric chloride and naphthalene balls. After field survey and herbarium preparation, all plants were identified by botanical name and family with the help of available literature. The collected plants materials have been deposited in the herbarium of dept. of Botany, K.M. Govt. College Narwana. Methodology was covered in two phases as follows.

1. Field survey-The survey was conducted to collect information about the plant species like their identification and documentation in the form of Botanical name and family. The whole campus was visited many times for the collection of plants.
2. Literature collection-The identification was also done based on literature study (Hooker, 1875; Maheshawari 1963; Jain, 1968; Bhandari, 1978; Jain et al., 2000; Kumar, 2001).

\section{Results and Discussion}

The Plant diversity is the functional and structural unit of the biotic components of ecosystem and is subjected to change due to the interaction of biotic and abiotic factors of the environment. On the basis of field survey of campus plants, 85 species showed their presence in the campus which were collected, identified and listed as shown in Table-1 and 2. Out of these plant species 34 species were of trees and 51 were of herbs and shrubs. Amongst the trees, most of the tree species were planted in collaboration with forest department, Haryana and species of herbs and shrubs were characterized by natural vegetation.

Poaceae was reported as the dominant family. Other main contributing families were Fabaceae (with its subfamilies like Caesalpinidae, Papillionadae, Mimosoidae), Solanaceae, Apocynaceae Euphorbiaceae and Asteraceae. The dominance of plants from Poaceae family in the study area indicates the harsh environmental conditions especially the water stress, because the species of Poaceae have made morphological, anatomical and physiological adaptations to overcome the drought conditions (Vasistha et al., 2010). Dominance of Fabaceae shows that these areas are nutrient deficient up to some extent especially nitrogen (Manhas et al., 2010; Vasistha et al., 2010). A large number of workers have provided useful botanical information through their publications. Works of Hooker (1875); Benthom and Hooker, (1876); Chopra et al., (1956); Maheshwari (1963); Bhandari (1978); 
Meenakshi and Sharma (1985); Jain, 1979; Kumar (2001) have given description of various plant species in literal form.
Therefore available literature was consulted for documentation of present research work.

Table.1 List of plants species with tree habit

\begin{tabular}{|c|c|c|}
\hline Botanical Name & Family & Habit \\
\hline Ficus benghalensis Linn. & Moraceae & Tree \\
\hline Ficus religiosa Linn. & Moraceae & Tree \\
\hline Ficus benjamina Linn. & Moraceae & Tree \\
\hline Callistemon citrinus (Curtis) Stapf. & Myrtaceae & Tree \\
\hline Tamarix aphylla Linn. & Tamaricaceae & Tree \\
\hline Ficus carica Linn. & Moraceae & Tree \\
\hline Polyalthia longifolia Sonn. & Annonaceae & Tree \\
\hline Mangifera indica Linn. & Anacardiaceae & Tree \\
\hline Kigelia pinnata (Jack.) DC. & Bignoniaceae & Tree \\
\hline Alstonia scholaris (Linn.) R. Br. & Apocynaceae & Tree \\
\hline Cassia fistula Linn. & Fabaceae & Tree \\
\hline Emblica officinalis Gaertn. & Euphorbiaceae & Tree \\
\hline Bombax ceiba Linn. & Bombacaceae & Tree \\
\hline Thuja orientalis Linn. & Cupressaceae & Tree \\
\hline Terminalia arjuna (Roxb.) Wight \& Arn. & Combretaceae & Tree \\
\hline Eucalyptus citriodora Hook. & Myrtaceae & Tree \\
\hline Azadirachta indica A. Juss. & Meliaceae & Tree \\
\hline Melia azedarach Linn. & Meliaceae & Tree \\
\hline Dalbergia sissoo (Roxb.) DC. & Fabaceae & Tree \\
\hline $\begin{array}{l}\text { Oreodoxa regia Kunth Syn. Roystonea regia } \\
\text { (Kunth) O.F. Cook }\end{array}$ & Arecaceae & Tree \\
\hline $\begin{array}{l}\text { Eugenia jambolana Lam. Syn. Eugenia cumini (Linn.) } \\
\text { Druce }\end{array}$ & Myrtaceae & Tree \\
\hline Accacia nilotica (Linn.) Willd. & Fabaceae & Tree \\
\hline Prosopis juliflora (Sw.) DC. & Fabaceae & Tree \\
\hline Prosopis cineraria ( Linn.) Druce & Fabaceae & Tree \\
\hline Aegle marmelos (Linn.) Correa Serr. ex Roxb. & Rutaceae & Tree \\
\hline Bauhinia variegate Linn. & Fabaceae & Tree \\
\hline Zizyphus jujuba Mill. & Rhamnaceae & Tree \\
\hline Albizzia lebbeck (Linn.) Willd. & Fabaceae & Tree \\
\hline Nyctanthes arbor-tristis Linn. & Oleaceae & Tree \\
\hline Ailanthus excels Roxb. & Simaroubaceae & Tree \\
\hline Morus alba Linn. & Moraceae & Tree \\
\hline Phoenix sylvestris Linn. & Arecaceae & Tree \\
\hline Psidium guajava Linn. & Myrtaceae & Tree \\
\hline Butea monosperma (Lamk.) Taub. & Fabaceae & Tree \\
\hline
\end{tabular}


Table.2 List of plants species with herb and shrub habit-

\begin{tabular}{|c|c|c|}
\hline Botanical Name & Family & Habit \\
\hline Adhatoda vasica Linn. & Acanthaceae & Shrub \\
\hline Ageratum conyzoides Linn. & Asteraceae & Herb \\
\hline Aloe barbadensis Linn. & Liliaceae & Herb \\
\hline Asparagus racemosus Willd. & Liliaceae & Herb \\
\hline Barleria prionitis Linn. & Acanthaceae & Herb \\
\hline Calotropis procera (Ait.) R.Br. & Asclepiadaceae & Shrub \\
\hline Canna indica Linn. & Zinziberaceae & Herb \\
\hline Vinca rosea Linn. & Apocynaceae & Herb \\
\hline Coleus forskohlii Auct. & Lamiaceae & Herb \\
\hline Cynodon dactylon (Linn.) Pers. & Poaceae & Herb \\
\hline Cyperus rotundus Linn. & Cyperaceae & Herb \\
\hline Datura innoxia Linn. & Solanaceae & Herb \\
\hline Eclipta alba (Linn.)Hassk & Asteraceae & Herb \\
\hline Cassia tora Linn. & Fabaceae & Herb \\
\hline Euphorbia hirta Linn. & Euphorbiaceae & Herb \\
\hline Tagetes erecta Linn. & Asteraceae & Herb \\
\hline Hibiscus rosa -sinensis Linn. & Malvaceae & Shrub \\
\hline Nerium indicum Mill. & Apocynaceae & Shrub \\
\hline Phyllanthus niruri (Sensu) Hook. f. & Euphorbiaceae & Herb \\
\hline Rosa indica Linn. & Rosaceae & Shrub \\
\hline Sida acuta Linn. & Malvaceae & Herb \\
\hline Achyranths aspera Linn. & Amaranthaceae & Herb \\
\hline Argemone mexicana Linn. & Papaveraceae & Herb \\
\hline $\begin{array}{l}\text { Solanum Xanthocarpum Linn. Syn. } \\
\text { Solanum surrattense Burm.F. }\end{array}$ & Solanaceae & Herb \\
\hline Solanum nigrum Linn. & Solanaceae & Herb \\
\hline Withania somnifera (Linn.) Dunal & Solanaceae & Herb \\
\hline Tribulus terrestris Linn. & Zygophyllaceae & Herb \\
\hline Parthenium hysterophorus Linn. & Asteraceae & Herb \\
\hline Chenopodium album Linn. & Chenopodiaceae & Herb \\
\hline Oxalis corniculata Linn. & Oxalidaceae & Herb \\
\hline Vicia sativa Linn. & Fabaceae & Herb \\
\hline Cannabis sativa Linn. & Cannabinaceae & Herb \\
\hline Boerhaavia diffusa (Linn.) Nom. Cons. & Nyctaginaceae & Herb \\
\hline Tridax procumbens Linn. & Asteraceae & Herb \\
\hline Croton bonplandianum Baill. & Euphorbiaceae & Herb \\
\hline Amaranthus caudatus Linn. & Amaranthaceae & Herb \\
\hline Launaea asplenifolia (Willd.) Hook. F. & Asteraceae & Herb \\
\hline Fumaria indica (Haussk.) Pugsley & Fumariaceae & Herb \\
\hline $\begin{array}{l}\text { Malvastrum coromandelianum (Linn.) } \\
\text { Garcke. }\end{array}$ & Malvaceae & Herb \\
\hline Lathyrus odoratus Linn. & Fabaceae & Herb \\
\hline
\end{tabular}




\begin{tabular}{|l|l|l|}
\hline Ranunculus sceleratus Linn. & Ranunculaceae & Herb \\
\hline Abutilon indicum Linn. & Acanthaceae & Herb \\
\hline Aristida setacea Retz & Poaceae & Herb \\
\hline $\begin{array}{l}\text { Cymbopogon citratus (DC. ex Nees) } \\
\text { Stapf }\end{array}$ & Poaceae & Herb \\
\hline Dicanthium annulatum (Forsk.) Stapf & Poaceae & Herb \\
\hline $\begin{array}{l}\text { Heteropogon contortus } \text { (Linn.) Beauv. } \\
\text { ex Roem. \& Schult.) }\end{array}$ & Poaceae & Herb \\
\hline Setaria glauca (Linn.) Beauv. & Poaceae & Herb \\
\hline $\begin{array}{l}\text { Scirpus } \text { litoralis Schrad Syn. } \\
\text { Schoenoplectus litoralis Schrad. }\end{array}$ & Cyperaceae & Herb \\
\hline Coronopus didymus (Linn.) Smith & Brassicaceae & Herb \\
\hline Sisymbrium irio Linn. & Brassicaceae & Herb \\
\hline Xanthium strumarium Linn. & Asteraceae & Herb \\
\hline
\end{tabular}

In order to maintain the ecological balance and to further sustainable development, plant species of economic and ecological importance are present in the study area. So these plant species superficially depict the composition of flora of Narwana sub divisional area. However, composition of annual herbaceous flora may vary in different seasons. Therefore these species can be utilized keeping in view the idea of sustainable development and utilization.

\section{Acknowledgement}

The corresponding author is highly thankful to all co- authors of this paper for providing available literature, indexes, floras, manuals, monographs and taxonomic keys for identification of plant species.

\section{References}

Benthom, G., Hooker, J.D. 1876. Genera Plantarum in 3 Volumes, L. Reeve and Co. London, United Kingdom.

Bhandari, M.M. 1978. Flora of Indian Desert, Scientific Publisher Jodhpur, India.

Chopra , R.N., Nayer, S.L., Chopra, I.C. 1956. Glossary of Indian Medicinal
Plants, CSIR, New Delhi, India.

Curtis, J.T., Cottom, G. 1956. Plant Ecology

Workbook- Laboratory Field

Reference Manuals, Burgess

Publication Co. Minnesota U.S.A.

Hooker, J.D. 1875. Flora of British India, Reeve \& Co Ltd., England.

Jain, S.K., Rao, R.R. 1977. Handbook of Field and Herbarium Methods. Today and Tomorrow Printer and Publications, New Delhi, India.

Jain, S.K. 1968. Medicinal Plants, National Book Trust, India. pp.1-126.

Jain, S.P. 1979. Flora of Haryana, Ph.D. Thesis, Department of Botany, Kurukshetra University, Kurukshetra, India.

Jain, S.P., Singh, S.C., Verma, D.M., Singh, J.S., Kumar, S. 2000. Flora of Haryana, CIMAP, Lucknow, India.pp.1-266.

Kumar, S. 2001. Flora of Haryana, Bishan Pal and Mahender Co. Dehradoon, India.

Maheshwari, J.K. 1963. Flora of Delhi, CSIR, New Delhi, India.

Manhas, R.K., Singh, L., Vasistha, H.B., Negi, M. 2010. Diversity of Protected Ecosystems of Kandi Region of Punjab, India. New York Sci. J., 3(4): 96-103. 
Meenakshi, Sharma M.1985. Flora of Ropar District, Dev Publishers, Patiala, Punjab, India.

Misra, R. 1968. Ecology Workbook. Oxford and IBH Publishing Co., New Delhi, India.

Phillips, E.A. 1959. Methods of vegetation study, Henry Holt, Rinehart and Winston New York,U.S.A.
Vasistha, H.B., Manhas, R.K., Singh, L., Negi, M., Sharma, J. 2010. Impact of Disturbances on Biodiversity Status, Resource Availability and their Management for Sustainable Development in Kandi Area of Punjab. Punjab Forest Department, Chandigarh.

\section{How to cite this article:}

Surender Kumar, Sunita Duggal, J.S. Laura, Narender Singh and Rajdeep Kudesia. 2016. Phyto-Diversity on Campus of K.M. Government College Narwana, India. Int.J.Curr.Microbiol.App.Sci. 5(7): 565-570. doi: http://dx.doi.org/10.20546/ijcmas.2016.507.062 